\title{
Strategies to De-Escalate the Conflict of Yogyakarta International Airport Construction
}

\author{
${ }^{1}$ DELVIRA NOVASANDA CHESARY PUTRI, ${ }^{2}$ CAROLINE PASKARINA
}

\begin{abstract}
${ }^{1}$ Undergraduate Program of Political Science, Faculty of Social and Political Science, Universitas Padjadjaran, Jalan Raya Bandung-Sumedang Km. 21 Jatinangor, Indonesia, ${ }^{2}$ Department of Political Science, Faculty of Social and Political Science, Universitas Padjadjaran, Jalan Raya Bandung-Sumedang Km. 21 Jatinangor, Indonesia email: ${ }^{1}$ delvira.novasanda@gmail.com; ${ }^{2}$ caroline.paskarina@unpad.ac.id
\end{abstract}

\begin{abstract}
The policy on the construction of Yogyakarta International Airport was responded with a rejection by the public that ended in quite a prolonged conflict. The conflict occurred because of the competing interests between the interests of the government to build an airport and the interests of the residents to stay in that location. In seven years since 2011, the conflict had de-escalated quite significantly from 2018 to 2019. This research analyzes strategies for conflict de-escalation, in which negotiation and mediation become its operating method. Researchers used a qualitative approach to extract data from actors involved in the conflict, namely the community living in the three villages most affected by the airport construction, representatives from Angkasa Pura I as the airport management authority, and representatives from the Local Government. In-depth interviews were conducted with ten key informants determined by purposive technique. The result of this research shows that the de-escalation of the conflict was managed to achieve through a persuasive approach that involved all of those concerned.
\end{abstract}

Keywords: Yogyakarta International Airport, Conflict, Management of Conflict

\section{Introduction}

The policy on the construction of Yogyakarta International Airport is one of several airports that would be built as the realization of strategic projects that supported the National Strategic Tourism Zone in Indonesia. It is as specified in the official document of national planning, titled the 2015-2019 National Medium-Term Development Planning, arranged during the administration of Joko Widodo to establish connectivity between regions and to open the access of the economy and tourism in the region of South Java (Badan Perencanaan Pembangunan Nasional Republik Indonesia, 2014). The construction of the airport is also intended to fulfill the capacity of the airport in Yogyakarta since the Adisutjipto Airport has been overloaded (Saputri, 2019).

The construction of Yogyakarta International Airport required 587 hectares of area. As for the public test that previously had been conducted, it was based on the ease of renunciation of land, strategic location, the potential of economic advance, social impacts, and others that strengthen Kulon Progo as the location of the construction of the airport (PT. Angkasa Pura I, 2017). It was strengthened with the legal basis of Local Regulation Number 1 the Year 2012 on Spatial Planning of Kulon Progo the Years of 2012-2032 complemented by Law Number 2, 2012 on Land Acquisition in the Public Interest, Decree of Governor of Yogyakarta Special Region Number 68/KEP/2015, and the Cassation Verdict of the Supreme Court Number 456 K/TUN/2015 as elements that supported the construction of the international airport. There were at least five villages affected by the construction of the international airport, i.e. Jangkaran Village, Palihan Village, Glagah Village, Sindutan Village, Kebonrejo Village.

Received: July 13, 2020, Revision: October 21, 2020, Accepted: June 08, 2021

Print ISSN: 0215-8175; Online ISSN: 2303-2499. DOI: https://doi.org/10.29313/mimbar.v37i1.6412

Accredited Sinta 2 based on the decree No.10/E/KPT/2019 until 2024. Indexed by DOAJ, Sinta, Garuda, Crossreff, Dimensions 
In the implementation of the policy on the construction of Yogyakarta International Airport, PT Angkasa Pura I was directly appointed by the national government to be in charge of the construction. It is following the release of Presidential Regulation Number 98, 2017 on the Acceleration of the Construction and the Operation of the Airport in Kulon Progo and also Presidential Regulation Number 58, 2017 on the Acceleration of the Completion of National Strategic Projects. Angkasa Pura I directly obtained the mandate to perform the process of construction and operation of Yogyakarta International Airport. This regulation, later on, is operationalized in the Regulation of the President of the Republic of Indonesia Number 98, 2017, as a legal basis for Angkasa Pura I to perform the assignment mandated by the President. The mandate comprises funding, technical planning, acquisition of land, completion of construction, operation, business, and maintenance. These regulations gave authority and responsibility to Angkasa Pura I for the construction of the airport. In its execution, the Regency Government of Kulon Progo also released a regulation in 2016 to form a team named Tim Koordinasi Bandara Yogyakarta International Airport or the Coordination Team of the Yogyakarta International Airport. This team would accommodate and facilitate the needs of the public and Angkasa Pura I during the construction of the airport and acted as a mediator between the two parties.

Meanwhile, in practice, the policy on the construction of the airport was diversely responded to by the public, including resistance from the affected people. The rejection is because almost all parts of the area that would become the location of the airport construction were the property of the people that had occupied the area from generation to generation so that they were reluctant to sell their land to the government because they considered it to be inherited land. The land where the construction was located also involved the area owned by Paku Alam Ground (PAG), an adat-based property right, therefore the people who occupied the ground did not have title to the area and they would lose their home. Moreover, the area used for the construction was productive because the majority of the people there were peasants (Pamungkas \& Bayu, 2017). This rejection then triggered quite a prolonged conflict because there were fundamental differences of interests between the conflicting parties (Fitriantoro, 2020; Haekal, 2020).

The conflict over the construction of the airport had occurred for quite a long time since the beginning period of planning in 2012 and its insertion into the Master Plan for the Acceleration and Expansion of Economic Development of Indonesia (MP3EI) (Kementerian PPN/Bappenas, 2012). However, the construction had been postponed for six years and the stages of construction were not conducted until 2017, while at first the construction of the airport was planned to begin in 2014 .

The people opposing the construction frequently firmly rejected all matters related to the construction of the airport, including rejecting eviction and transfer of land's property rights. All processes of land acquisition conducted by Angkasa Pura I triggered action and resistance from the people who opposed it, hence the conflict continued to escalate. Action and resistance of the people were shown by staging street demonstrations, blockading streets, sealing village offices, and rejecting all forms of invitations for the socialization held by the government or the airport construction management. The people opposing the construction were supported by some activists and university students as a form of solidarity and public participation to criticize the policy that had been made because they considered it to violate the rights of the public. Besides that, the people also formed an organization as a forum for expressing the public's aspirations related to their rejection of the construction of the airport. This organization was known as Wahana Tri Tunggal (WTT).

For seven years the conflict had escalated; it started to de-escalate early in 2018 and continued to decrease until 2019 (Pritangguh \& Malik, 2019). The deescalation of the conflict shows that there were efforts and approaches of the conflicting parties to manage the conflict and discussed matters related to their interests to reach a point of compromise. It means there was an exchanging process to reach a compromise point occurring between Angkasa Pura I and the affected people who rejected the construction of the airport, therefore eventually the process of the construction of the airport could be continued again.

Conflicts in airport construction have also occurred in various other countries, 
mainly due to the very large land requirements for the airport area and its supporting facilities (Alazemi \& Mohiuddin, 2019; Stevens \& Baker, 2013). Several studies have identified several causes of conflict, such as the complexity of the megaproject itself (Eren, 2019; Lee et al., 2017; Liu et al., 2016), the spatial distribution of landscape values, values compatibility scoring, land use preference differences, and a combined values and preferences (Brown \& Raymond, 2014), the impact of the airport to livelihood, such as aircraft noise issue (da Silva et al., 2020), environmental issue (cokorilo, 2016), and the structure and function of city logistics and urban freight as well as airport-centric development (Boloukian \& Siegmann, 2016).

These studies have contributed greatly to identifying various factors that trigger community resistance around the airport area to development plans or to the existence of the airport itself. However, airport development cannot be seen only from a construction management perspective because the land to build the area is related to the public interest. The different interpretations of the public interest have made the development of the airport area a political issue. Feldhoff (2002) and Toor \& Ogunlana (2010) found the strategic role played by politicians, ministerial bureaucrats, and businessmen in determining airport policies and their strategies and interests. The same finding is also presented by Stevens \& Baker (2013) who reveal that airport area development is largely determined by land-use policies. This policy itself is a fragmented process as a result of current legislative and policy frameworks; competing stakeholder priorities and interests; and inadequate coordination and disjointed decision-making. These social conflicts can have negative effects on a construction project, and may even lead to a project becoming unsustainable (Brockman, 2014; Iswan Kaputra \& Prathiwi Widyatmi Putri, 2020).

Conflicts among external stakeholders have a significant impact on project performance as well as on social governance (Anderson \& Polkinghorn, 2008; Jia et al., 2011; Liu et al., 2016; Mteki et al., 2017; Wang et al., 2016). To manage conflicts effectively, conflicts must first be recognized, and alternatives systematically presented using a systematic approach (Li et al., 2013; Naderpajouh et al., 2014; Zuliyah et al., 2020). Conflict in the development of the Yogyakarta international airport area is also inseparable from multiple interpretations of government policies at the macro level. However, this article will focus more on the strategies used to reduce the escalation of a conflict so that a consensus can be obtained from the affected communities in the three villages around the airport area. This article focused on the period of 2018-2019 because during this period the escalation of the conflict decreased drastically, therefore it needs further study on why the decrease in the escalation of the conflict could occur. The discussion in this writing is focused on negotiations and mediation as a method of conflict management that led to the deescalation of the conflict.

\section{Research Methodology}

This research applied the qualitative research method. Qualitative research intends to understand holistically the phenomenon of what the subject of the research experiences by describing it in the form of words and languages in a natural specific context by utilizing a variety of scientific methods (Moleong, 2012).

The data collection techniques applied in this research were primary data. These primary data were obtained by using the method of in-depth interviews to get the information that would be sought, that is, by performing questions and answers directly and orally with parties related to the problem being studied. This method was adopted to gather information directly from the resource persons involved in the conflict over the construction of the international airport in Kulon Progo. The research informants are actors involved in the conflict, namely the community living in the three villages most affected by the airport construction, representatives from Angkasa Pura I as the airport management, and representatives from the Local Government. In-depth interviews were conducted with ten key informants, determined by purposive technique.

Data then analyzed through interpretation techniques to identify key themes to explain the strategies of conflict's de-escalation.

\section{Results and Discussion}

Fitriantoro (2020) explained that the drivers of conflicts caused by the construction 
and development of infrastructure were related to not only the development of infrastructure but also a land conflict that arose from urban development policies. A conflict may become serious and lengthy if it is left to be prolonged without resolution, whereas a conflict managed appropriately will become a positive potential, hence it can minimize damage, leading to the condition of the de-escalation of the conflict that may encourage the development of peace (Brown \& Raymond, 2014; Lee et al., 2017; Zuliyah et al., 2020; Zuliyah \& Absori, 2019).

Based on the perspectives of politics and interests, the conflict over the construction of Yogyakarta International Airport (YIA) emerged because there was an upheaval and a gap of interests between the public and Angkasa Pura I related to the land that would be used for the construction of the airport, which caused opposition from a group of people to the policy on the construction of the YIA Airport. According to the Coordination Team of the YIA Airport in an interview session, the purpose of the construction of the airport was to achieve the progress of the people of Kulon Progo and to be a symbol of the pioneer of progress for the people. Talking about the context of progress, certainly, there were no differences in interests between the government and the public because all parties wanted to progress. Although the construction of the airport had the same interest-that is, in the name of progress and prosperity-in reality, the conflict still occurred. It means that it was not the progress that became the source of dispute, but there were some other micro things taken into consideration by the people that eventually some of them put up resistance as a form of rejection to the airport.

The people's rejection emerged from the historical and emotional bond between the people and the land they occupied. The background of this historical bond was the fact that they grew and developed on the land from generation to generation and they considered it their inherited land that it was not easy to leave the land. Besides that, some of the affected people were peasants; therefore they worried about their fate in the future because they would lose their tilled soil. The peasants had contributed to the fertility of the soil in Temon District that eventually this region contributed quite a high yield of crop production from their farm and plantation. As affirmed by the residents, they were reluctant to leave their ancestors' land and their continued survival in the future became the most serious consideration because changing professions was not an easy thing to do for them. These matters then were called more micro interests from the side of the affected people. Undeniably, every society wants prosperity but we cannot negate that some smaller interests became the basic reason for their resistance.

These interests then need to be balanced and to manage that eventually each of the conflicting parties meets at a compromise point so that the conflict may de-escalate. The process of meeting at a compromise point can be conducted through negotiations and mediation as an effort to manage the conflict. In the context of the researchers' discussion, negotiations and mediation were conducted at the same time; therefore we cannot negate one thing or another because in practice both things are conducted simultaneously. Through the method of negotiations and mediation, it is hoped that the interests can be accommodated and balanced so that the compromise point between the conflicting parties can be reached.

Angkasa Pura I became the main actor in the construction of the YIA Airport as the State-Owned Enterprise that was directly assigned by the government to execute the strategic national project. Based on the mandate, it can be analyzed that the interest of Angkasa Pura I, in this case, is to ensure that the construction of the YIA Airport could be completed as planned in the name of the public interest so that all things that hindered the construction of the YIA Airport became the responsibility of Angkasa Pura I. It is following Regulation of the President of the Republic of Indonesia Number 58 the Year 2017 on the Acceleration of the Completion of National Strategic Projects.

Based on the data obtained in the field, it was found out that during the process of negotiations and mediation, Angkasa Pura I was pragmatic in dealing with the conflict that occurred. It was following what was revealed by some members of society and the Coordination Team of the YIA Airport that Angkasa Pura I was not hesitant to spend a lot of money to meet the needs and demands of the people who felt the impact. This attitude of Angkasa Pura I was due to the urge of interest to immediately finish the construction of the YIA Airport, which was 
projected to operate in 2019 after previously it was frequently postponed due to the same problem. It made Angkasa Pura I have the orientation to tasks and focus its attention to accomplish the tasks efficiently so that it could directly overcome matters that may disturb the work (Yukl, 2013).

In this case, the party considered to be a hindrance in performing the work from the government's side was the people who rejected the construction of the YIA Airport. Initially, the people who rejected it were grouped in an organization named Wahana Tri Tunggal. However, this organization was then split up because some of its members gradually changed their side to be proponents of the construction. Therefore, the people who firmly rejected it moved and were mobilized more based on solidarity and common suffering. According to the resource person, the people were supported by some activists and university students. The researchers have analyzed that the involvement of university students and activists in this conflict can be observed from two sides. As for the side of Angkasa Pura and the people who were pro-the construction, the presence of university students and activists was considered to be the appearance of agent provocateurs because they gave a new perception to the public. On the other side, the presence of university students and activists on the side of the people who were contra-the construction was a form of power balance by giving criticism and suggestions or staging solidarity actions so that the policy on the construction of the YIA Airport was made really for the interests of the public, not just for particular parties.

In balancing the interests, the Coordination Team of the YIA Airport was present as a group that actively strove for the management of the conflict. The Coordination Team of the YIA Airport was a team formed by the Regency Government of Kulon Progo that held the mandate from both parties, Angkasa Pura I and the people who felt the impact. Unlike Angkasa Pura I, the researchers analyzed that this team attempted to accommodate the interests brought by Angkasa Pura I with the interests of the affected people and the team emphasized negotiation. It means that this team brought both interests for the same importance and it could be realized on balance. The attitude of the Coordination Team of the YIA Airport was reflected in how they frequently provided assistance and facilitation for people who were in need during the process of paying compensation and relocation. On the other side, this team also frequently went for a consultation with Angkasa Pura I for every step they took to deal with the public and to encourage them to be able to obtain their rights although the construction of the airport was also the policy on the public interest. One of the resource persons who was also a former member of the Coordination Team of the YIA Airport revealed that it could not be denied that they considered the residents of Kulon Progo their siblings or even their children whose rights needed to be accommodated. The basis was that they were all from Kulon Progo. According to the analysis of the researchers, the relationship between the Coordination Team of the YIA Airport and the residents of Kulon Progo was based on the similarities in identity. This team maximally attempted to pay attention to the people and to watch over their rights so that they did not feel that their rights had been violated. It was as if the presence of the Coordination Team of the YIA Airport was a representation that the government was also present among the public in the effort to resolve the conflict.

After the construction of the airport had conflicted for seven years, from 2018 to 2019 de-escalation began to occur. This condition was caused by some matters that would be elaborated in the following findings of the research.

\section{A Shift in the Approach and Responses in Resolving the Conflict}

Based on the data obtained from interviews and other supporting documents, the approach conducted at the early stage of the construction (2012-2016) was still limited to the dissemination of information and massive public consultation, in which the people were gathered at the village administration buildings and received a general briefing related to the construction of the YIA Airport. According to the people, the conveyance of the aspirations was very limited because they were conveyed through the media of filling forms on paper. This effort was considered not to open twoway communication with the public and it caused a perception that suggestions from the public were merely received without any follow-up so that eventually the public felt that the government only accommodated 
the interests of the people who agreed to the construction of the YIA Airport and they did not take the people who opposed it into consideration. This matter made the people who were against the construction of the airport ignored all forms of the approach taken by the government and they resisted staying on their land because according to them this land problem could not be resolved just with compensation.

Dissemination of information and public consultation conducted at the early period of the construction stage did not result in an obvious two-way communication between the people and the government side. The process of the conveyance of the aspirations through public consultation also showed that the public was not provided with enough space to directly express their opinion, which means there was no two-way dialogue created at that time because there was a limitation of media in conveying their aspirations. The persuasive approach conducted at that time was not carried out intensively to the people who opposed it since the approach was conducted only to the people who were present at the dissemination of information and the public consultation. Therefore, the lack of persuasive approach conducted personally, the limitation of aspirations, and the feeling that they were ignored caused strong resistance from the public.

At the end of 2017, to be precise during the acquisition of the land towards the physical construction, the eviction was carried out massively. It was conducted not unfoundedly but on the ground that the land status had been changed, in which the title to the land had been transferred to the state since 2015 and the public had been given a year to move but until the end of 2017 many people had not yet moved although the compensation had been paid. Based on a conversation with a resource person, a clash once broke out between the forces of security and the people that still wanted to stay and it had an impact on the people's distrust of the government side because they felt the eviction was carried out forcibly.

Based on the data obtained from the Office of Land and Spatial Planning, since the beginning of 2018, the eviction had left behind 37 heads of the families that stayed resistant and remained at the location of the construction of the YIA Airport. They were scattered over Glagah Village and Palihan Village, two villages that felt the severest impact of the construction of the YIA Airport. Those who stayed were determined to stick to the same reason-that was, they did not want to be evicted from their land and they felt they never agreed to give their land to the government; hence, they still had the title to the land.

This condition began to encourage some parties to manage the conflict so that it would not become a prolonged one. This condition also refers to the prerequisites proposed by Bercovitch (1983) in conducting conflict management. The first is a low probability to achieve the purpose of the conflict. Based on the data that have been elaborated in the previous paragraph, the resistance put up by the people who stayed on their land although they had gone through some processes of approach in the forms of dissemination of information and public consultation shows a low probability to reach an agreement if the applied method was still the same because they had been apathetic about the dissemination of information and public consultation that had been conducted. Besides that, the number of families that firmly stayed was just 37 out of 518 heads of the families that scattered over Glagah Village and Palihan Village. This condition would make it difficult for the people to retain their land as the purpose of their conflict.

The second is that the diminishing purpose of the conflict does not commensurate with the cost spent, such as materials, time, opportunity, and others. Based on the result of interviews, the people had been aware that they could not retain their land even though they had put up much resistance; therefore the purpose was not as big as the initial one because the number of people who agreed to the construction of the airport was getting bigger. The cost spent by the people who were against the construction would be getting bigger if they retained their demand. Their land was isolated and the time spent fighting for the land was also wasted because the purpose of the conflict had diminished. However, the people kept putting up resistance because since the beginning they had gone too far in their resistance, hence if they halted their struggle, they would feel it was in vain. They kept putting up resistance as evidence for the presence of those who had struggled this far. Behind that, the resistant attitude of the people might increase their opportunity to get a better offer in exchange for the interest of the construction of the YIA Airport because 
it is related to an exchange of interests between the two sides.

The third is that there is a possibility for settlement by offering shared benefits over the prolonged conflict. It was shown by the side of Angkasa Pura I that had opened the opportunity for the settlement of the conflict by bringing it to the negotiation arena to achieve the shared interests. Angkasa Pura I also built a help desk at the project area of the construction of the YIA Airport, aiming to provide a comprehensive understanding related to the procedure and the process of the consignment of the compensation payment and to watch over the fulfillment of the rights of the people that felt the impact, so that it may open a dialogue between the public and the parties related to the construction process of the YIA Airport.

The fourth is the flexibility of each party to consider negotiation. Based on the condition that met the prerequisites, conflict management can be started by bringing the public to the negotiation arena, solely or accompanied by the third party (mediation). As mentioned previously, bringing conflicting parties to the process of negotiations and mediation will bring the opportunity to discuss interests and demands and also seek the best solution from the conflicting parties. It is done to accommodate the interests of the conflicting parties so that it would not become a prolonged conflict and remained controllable, because a well-managed conflict may lead to the de-escalation of the conflict. Moreover, at that time the construction of the YIA Airport had entered the process of land acquisition, therefore it was urgent to carry out some conflict management to deal with the people that remained resistant.

\section{Forms and Strategies of Negotiation and Mediation}

The process of negotiations in the settlement of the conflict of YIA Airport at this stage was more often carried out informally. The attitude of the people that shut their door tightly and refused to meet required a persuasive approach through informal meetings. These informal meetings were held by visiting the members of society one by one, door to door so that the approach was more personal. These meetings emphasized a persuasive approach, in which they discussed what the problems were and what offers could be given so that the interests could be accommodated. Apart from visiting the members of society one by one, Angkasa Pura I cooperated with the Regency Government of Kulon Progo to build the Center for Information Services Help Desk Yogyakarta International Airport at the area of the airport. This help desk became one of the channels for the public who needed information related to the procedure and process of the consignment of compensation payment and the public could visit the help desk independently when they wanted to open the dialog space with Angkasa Pura I related to the fulfillment of their rights.

There was the openness of information space and space for conveying aspirations as an important step to accommodate the interests of the public. The effort to intensively visit members of society also constituted a serious effort from the government to open a dialogue with the public to discuss the best solution for the conflict. Besides that, it was the right step to fix the relationship with the public personally so that when both sides conducted negotiations, they were in a good relationship and needed each other to reach a mutually beneficial agreement.

The condition of the public at that time was that they stood firmly on the principle of 'Pokoke', meaning whatever the reasons, they would not move and remained on their land. This condition made the process of negotiations require strategies for achieving particular goals because the conflicting parties were not able to understand each other's views as each party had their views that they considered right. The use of strategies of contending and problemsolving became two quite relevant strategies compared to the data in the field, while the use of the strategy of concession making became irrelevant because there was no reduction in demands, both from the side of Angkasa Pura I and the affected people. According to the affected people, there was once pressure from the side of Angkasa Pura I on the public, in which Angkasa Pura I imposed again the deadline they had set for the people to move immediately. It was revealed by a local village official because the construction of the airport could not be postponed any longer and the percentage of the people that rejected it was no fewer than $10 \%$ and the determination of the deadline minimized forced evictions because the title of the land had been transferred to the state. Apart from the determination of the deadline, the people also said that power cuts were 
once imposed as a serious bluff from the side of Angkasa Pura I.

Observing the data from the field, the researchers analyzed that the pressure put on by the side of Angkasa Pura I related to the time target they had to achieve to finish the construction of the airport as their main interests. Angkasa Pura I had sufficient power to do it because they had the legal basis of Law Number 2 the Year 2012 on Land Acquisition in the Public Interest and Presidential Regulation Number 98 the Year 2017 on the Acceleration of the Construction and the Operation of the Airport in Kulon Progo, hence referring to the basis, Angkasa Pura I just followed the procedure and the title of the land had been transferred to the state.

The other attempts made to persuade the side of the public were, among other things, offering them or their children jobs at the airport if they agreed to move. It was following what some resource persons from the public said that there was this kind of offer when the process of negotiations was conducted (Zuliyah \& Absori, 2019). On the other side, the Coordination Team of the YIA Airport claimed that so far Angkasa Pura I was very open-minded over demands raised by the affected people and tried to accommodate them by making coordination with the Coordination Team of the YIA Airport. It was a strategy that the offer from the owner of the project was a persuasive argument used for influencing other parties by placing a position that both parties were dependent on each other. In this case, Angkasa Pura I tried to influence the affected people with some offers so that they were willing to move. This was because the agenda they brought was to make sure that the construction of the YIA Airport could be carried out. They were not hesitant to spend some materials to meet the needs of the people and always open-minded over the offers from the public. Referring to Presidential Regulation Number 98 the Year 2017, it was stated that they were in full charge of the construction, including the project financing and the problems occurring in the field.

Besides that, the strategy of problemsolving was very helpful in straightening the interests of both sides, hence each side did not have views they considered right, and they could accept the other side's views. Through this strategy, each side was demanded to be a good listener so that every interest could be well accommodated and to find the best solution for every existing problem. Based on the statement of a member of the Coordination Team of the YIA Airport, during the process of negotiations, each member of society was identified for their problems and then the solution and agreement were sought. The presence of the Coordination Team of the YIA Airport was very helpful in the process of negotiations and guarding the fulfillment of the needs of the public. It was based on the statement of the public during the interviews that the team was cooperative enough and very helpful in accommodating aspirations, and they became active listeners and were very helpful in dealing with administrative matters during the relocation.

According to the statement of the Coordination Team of the YIA Airport, the process of negotiations and mediation at least took less than a year until eventually all members of society could be completely moved. During the process, demonstrations staged by the people that rejected the construction had decreased because each side began to focus on the best agreement that can be achieved. These negotiations and mediation discussed matters of compensation for land, substitution for agricultural land, free relocation, and jobs for the future. The result of the agreement changed the attitude of the resisting people that eventually they loosened their defense and were willing to be relocated. There was the distribution of power in the process, which was shown in the process of negotiations to seek the meeting point between the conflicting parties to balance the existing interests. It became a strategy for building a relationship pattern that caused interdependence between various parties.

The assistance and explanation provided by the Coordination Team of the YIA Airport also contributed to making the people change their minds, and even at the point where they had changed their minds, this team still assisted them in the administration matter. Besides that, the leadership of the Regent of Kulon Progo who took part in going out to the field created an image that the local government was also present and thought about their people. It was supported by some data from the resource person that during the process of mediation, Regent Hasto went and met with the people personally and informally. 
This kind of approach allowed the public to talk about matters that constituted demands, restlessness, and interests so that the people felt they were counted. It is following prerequisites that must be met to resolve the conflict effectively, that the rights of each side must be counted, considered, and fulfilled. Then, a new dialogue can be started as a process of settlement to seek the meeting point so that the conflict can be managed and de-escalated (Herry, 2012).

\section{Conclusions}

De-escalation of the conflict over the construction of the YIA airport occurred because the effort of negotiations and mediation emphasized personal approaches between the conflicting parties. This personal or individual approach was conducted to accommodate the interests of each member of society until eventually, they met at a compromise point. Through this approach, the public felt they were counted and all of their interests and demands were accommodated. Meanwhile, the emphasis on the interests and demands given by the conflicting parties was part of the process of negotiations and mediation to influence the decision to each other. Therefore, the management of the conflict through negotiations and mediation may become a way to decrease the intensity of the conflict without having to cause damage to the others because it will create a relationship better than before.

\section{References}

Alazemi, M., \& Mohiuddin, A. (2019). Construction Project in Kuwait International Airport Cargo City: Issue of Conflict Management. International Journal of Engineering Materials and Manufacture, 4(2), 59-65. https://doi. org/10.26776/ijemm.04.02.2019.03

Anderson, L. L., \& Polkinghorn, B. (2008). Managing conflict in construction megaprojects: Leadership and thirdparty principles. Conflict Resolution Quarterly, 26(2), 167-198. https://doi. org/10.1002/crq.229

Badan Perencanaan Pembangunan Nasional Republik Indonesia. (2014). Rencana Pembangunan Infrastruktur 2015-2019 dan Alokasi APBN 2015.

Bercovitch, J. (1983). Conflict and Conflict Management in Organizations: A Framework for Analysis. Hong Kong
Journal of Public Administration, 5(2), 104-123. https://doi.org/10.1080/0252 9165.1983.10800140

Boloukian, R., \& Siegmann, J. (2016). Urban Logistics; a Key for the AirportCentric Development - A Review on Development Approaches and the Role of Urban Logistics in Comprehensive Airport-Centric Planning. Transportation Research Procedia, 12, 800-811. https:// doi.org/https://doi.org/10.1016/j. trpro.2016.02.033

Brockman, J. L. (2014). Interpersonal Conflict in Construction: Cost, Cause, and Consequence. Journal of Construction Engineering and Management, 140(2), 04013050. https://doi.org/10.1061/ (asce)co.1943-7862.0000805

Brown, G., \& Raymond, C. M. (2014). Methods for identifying land use conflict potential using participatory mapping. Landscape and Urban Planning, 122, 196-208. https://doi.org/https://doi. org/10.1016/j.landurbplan.2013.11.007

Čokorilo, O. (2016). Environmental Issues for Aircraft Operations at Airports. Transportation Research Procedia, 14, 3713-3720. https://doi.org/https://doi. org/10.1016/j.trpro.2016.05.491

da Silva, B. A. C., Santos, G. S., \& Gomes, R. de A. (2020). Land use policy in the vicinity of airports: Analysis and lessons learned from the Brazilian situation. Land Use Policy, 90, 104314. https:// doi.org/https://doi.org/10.1016/j. landusepol.2019.104314

Eren, F. (2019). Top government hands-on megaproject management: the case of Istanbul's grand airport. International Journal of Managing Projects in Business, 12(3). https://doi.org/10.1108/ IJMPB-02-2018-0020

Feldhoff, T. (2002). Japan's regional airports: conflicting national, regional and local interests. Journal of Transport Geography, 10(3), 165-175. https:// doi.org/https://doi.org/10.1016/S09666923(02)00009-1

Fitriantoro, M. I. (2020). Drivers of Conflict in Urban Infrastructure: Case Study of the New Yogyakarta Airport. Jurnal Politik, 6(1). https://doi.org/10.7454/ jp.v6i1.214

Haekal, L. (2020). Ekspansi Geografis dan Perampasan Lahan: Sisi Lain Pembangunan Yogyakarta International Airport. Politika: Jurnal IImu Politik, 11(1). https://doi.org/10.14710/ politika.11.1.2020.31-52 
Herry, M. (2012). Kearifan Lokal dalam menyelesaikan Konflik Agraria. UINMaliki Press.

Iswan Kaputra, \& Prathiwi Widyatmi Putri. (2020). The Precarity of Peri-urban Resistance: A Resistance to the Forced Eviction of Pasar VI Village and the Development of Kualanamu International Airport, North Sumatera. PCD Journal, 8(1). $\quad$ https://doi.org/10.22146/pcd. v8i1.419

Jia, G., Yang, F., Wang, G., Hong, B., \& You, R. (2011). A study of megaproject from a perspective of social conflict theory. International Journal of Project Management, 29(7), 817-827. https:// doi.org/10.1016/j.ijproman.2011.04.004

Kementerian PPN/Bappenas. (n.d.). Master Plan Percepatan dan Perluasan Pembangunan Ekonomi Indonesia (MP3EI) 2011-2025.

Lee, C., Won, J. W., Jang, W., Jung, W., Han, S. H., \& Kwak, Y. H. (2017). Social conflict management framework for project viability: Case studies from Korean megaprojects. International Journal of Project Management, 35(8), 1683-1696. https://doi.org/https://doi. org/10.1016/j.ijproman.2017.07.011

Li, T. H. Y., Ng, S. T., \& Skitmore, M. (2013). Evaluating stakeholder satisfaction during public participation in major infrastructure and construction projects: A fuzzy approach. Automation in Construction, 29, 123-135. https://doi. org/10.1016/j.autcon.2012.09.007

Liu, Z. Zhao, Zhu, Z. Wei, Wang, H. Jia, \& Huang, J. (2016). Handling social risks in government-driven mega project: An empirical case study from West China. International Journal of Project Management, 34(2), 202-218. https:// doi.org/10.1016/j.ijproman.2015.11.003

Mteki, N., Murayama, T., \& Nishikizawa, S. (2017). Social impacts induced by a development project in Tanzania: a case of airport expansion. Impact Assessment and Project Appraisal, 35(4). https://doi. org/10.1080/14615517.2017.1322806

Naderpajouh, N., Mahdavi, A., Hastak, M., \& Aldrich, D. P. (2014). Modeling Social Opposition to Infrastructure Development. Journal of Construction Engineering and Management, 140(8),
04014029. https://doi.org/10.1061/ (asce)co.1943-7862.0000876

Pamungkas, B., \& Bayu, A. (2017). Prahara Mega Proyek Pembangunan Bandara Kulon Progo.

Pritangguh, M., \& Malik, I. (2019). Agrarian Conflict Resolution in Construction of New Yogyakarta International Airport (Nyia) in Kulon Progo. Prodi Damai Damai Dan Resolusi Konflik, 5(1), 17-38.

PT.Angkasa Pura 1. (2017). Laporan Bandara Internasional Yogyakarta.

Saputri, M. (2019). Penerbangan Adisutjipto Dipindah ke BIY Kulon Progo September ini. Tirto.Id. https://tirto.id/ penerbangan-adisutjipto-dipindah-kebiy-kulon-progo-september-ini-ecC5

Stevens, N., \& Baker, D. (2013). Land Use Conflict Across the Airport Fence: Competing Urban Policy, Planning and Priority in Australia. Urban Policy and Research, 31(3), 301-324. https://doi. org/10.1080/08111146.2013.785943

Toor, S. ur R., \& Ogunlana, S. O. (2010). Beyond the "iron triangle": Stakeholder perception of key performance indicators (KPIs) for large-scale public sector development projects. International Journal of Project Management, 28(3), 228-236. https://doi.org/10.1016/j. ijproman.2009.05.005

Wang, T., Tang, W., Du, L., Duffield, C. F., \& Wei, Y. (2016). Relationships among Risk Management, Partnering, and Contractor Capability in International EPC Project Delivery. Journal of Management in Engineering, 32(6), 04016017. https:// doi.org/10.1061/(asce)me.19435479.0000459

Yukl, G. A. (2013). Leadership in Organizations. Pearson.

Zuliyah, S., \& Absori, A. (2019). Settlement of Land Acquisition Conflicts in the Contraction of International Airport in Yogyakarta Special Region. International Journal of Psychosocial Rehabilitation, 23(4). https://doi.org/10.37200/ijpr/ v23i4/pr190418

Zuliyah, S., Absori, Harun, \& Sudjito. (2020). Patterns of social justice based conflict resolution in land procurement: A case study in Yogyakarta international airport development. International Journal of Innovation, Creativity and Change, 12(12). 